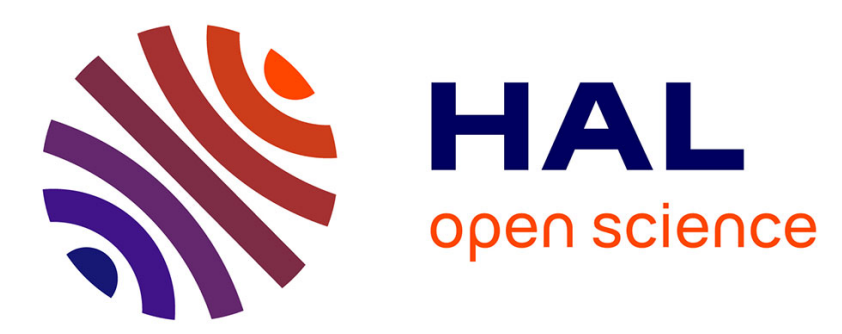

\title{
Direct subphthalocyanine conjugation to bombesin vs indirect conjugation to its lipidic nanocarrier
}

Yann Bernhard, Elodie Gigot, Victor Goncalves, Mathieu Moreau, Nicolas Sok, Philippe Richard, Richard A Decréau

\section{- To cite this version:}

Yann Bernhard, Elodie Gigot, Victor Goncalves, Mathieu Moreau, Nicolas Sok, et al.. Direct subphthalocyanine conjugation to bombesin vs indirect conjugation to its lipidic nanocarrier. Organic \& Biomolecular Chemistry, 2016, 10.1039/C6OB00530F . hal-03471289

\section{HAL Id: hal-03471289 \\ https://hal.science/hal-03471289}

Submitted on 8 Dec 2021

HAL is a multi-disciplinary open access archive for the deposit and dissemination of scientific research documents, whether they are published or not. The documents may come from teaching and research institutions in France or abroad, or from public or private research centers.
L'archive ouverte pluridisciplinaire HAL, est destinée au dépôt et à la diffusion de documents scientifiques de niveau recherche, publiés ou non, émanant des établissements d'enseignement et de recherche français ou étrangers, des laboratoires publics ou privés. 
Received 00th January 20xx, Accepted 00th January 20xx

DOI: $10.1039 / x 0 x x 00000 x$

www.rsc.org/

\section{Direct subphthalocyanine conjugation to bombesin vs indirect conjugation to its lipidic nanocarrier}

\author{
Yann Bernhard, ${ }^{\text {a }}$ Elodie Gigot, ${ }^{\text {a }}$ Victor Goncalves, ${ }^{\text {a }}$ Mathieu Moreau, ${ }^{\text {a }}$ Nicolas Sok, ${ }^{\text {b }}$ Philippe \\ Richard, ${ }^{\text {a }}$ Richard A. Decréau*a
}

\begin{abstract}
Bombesin (BBN) was covalently bound to graftable subphthalocyanine (SubPc) or to a cholesterol derivative, a component of a liposome that encapsulates non graftable SubPc. The latter bioconjugation approach was suitable to address the stability of SubPc and was achieved by copper-free click-chemistry on the outer-face of the liposome. Liposomes were purified (FPLC) then analyzed in size (outer diameter about $60 \mathrm{~nm}$ measured by DLS). In vitro binding studies allowed to determine the $\mathrm{IC}_{50} 13.9 \mathrm{nM}$ for one component of the liposome, cholesterol, conjugated to BBN. Hence, azido- (or alkynyl-) liposomes give fluorophores with no reactive functional group available on their backbone a second chance to be (indirectly) bioconjugated (with bombesin).
\end{abstract}

\section{Introduction}

Optical Imaging (OI) of cancer models has a promising future in preclinical imaging, as it has the possibilities to image noninvasively. $^{1}$ In the search of new fluorophores, ${ }^{2}$ subphthalocyanines (SubPc) are interesting probes for OI, especially because of their domed geometry that does not favour aggregation, ${ }^{3 a-b}$ which is an interesting approach compared to other approaches developed to prevent aggregation. ${ }^{4 a-c}$ Moreover, these new probes in the field of preclinical imaging have emission wavelengths in the greenorange region of the spectrum (around $570 \mathrm{~nm}$ ). Preliminary in vitro studies have shown the relevance of SubPcs (either in solution or entrapped in liposomes), that fit well in the Lavis \& Raines diagram. ${ }^{5}$ However, conjugation of probes to biomolecules is a necessary step to ensure site-selectivity. Such an approach had been previously reported for SubPc with testosterone. ${ }^{6}$ Herein, we present two strategies to achieve the conjugation to bombesin (7-14) (BBN), a well known peptide the receptor of which is over-expressed at the surface of tumor cells and that has been conjugated to several probes. ${ }^{7 a-c}$ One strategy consisted in entrapping SubPc in a liposome and to subsequently graft BBN to the SubPccontaining liposome to afford biovectorized liposome 1ab. One strategy consisted in binding BBN and SubPc covalently to afford SubPc-BBN conjugates 2ab. Herein, these two approaches, i.e. direct vs indirect, are developed and compared (Fig. 1).

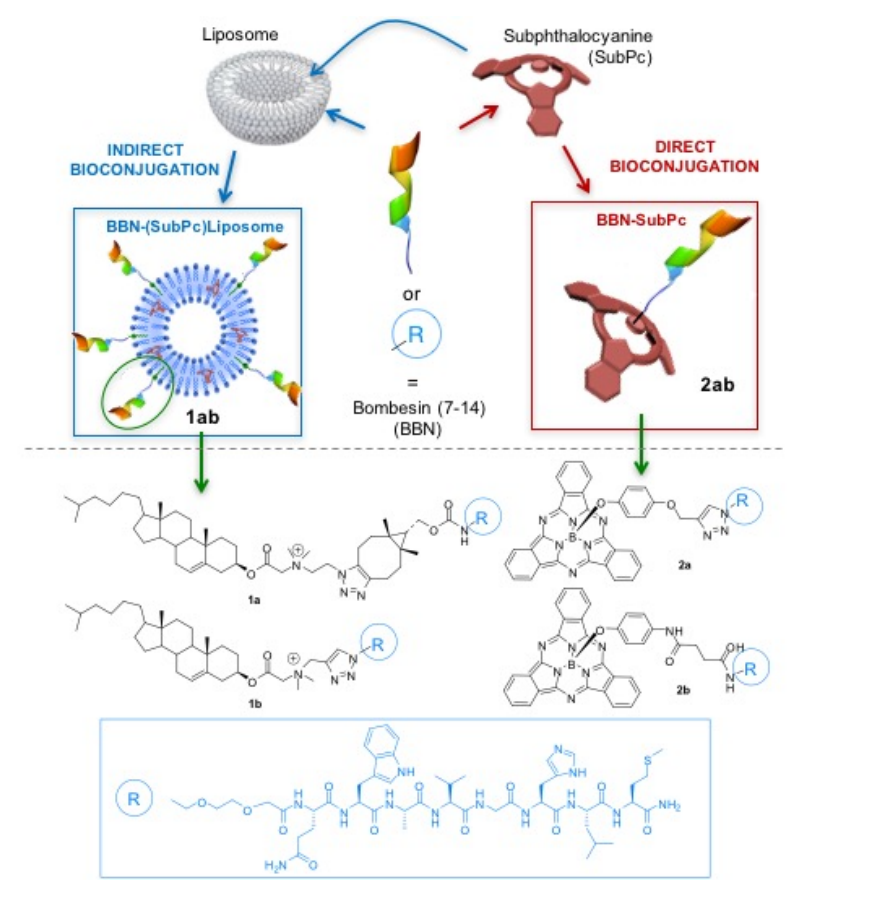

Fig. 1. General Bioconjugation Strategies: SubPc-BBN (direct bioconjugation) vs liposome-BBN encapsulating non graftable SubPc (indirect bioconjugation).

\section{Results and discussion}

\section{Synthesis of precursors for bioconjugation.}

(i) Subphthalocyanines. The conjugation of SubPc to BBN was achieved either by peptide coupling or by click chemistry. The latter required the synthesis of alkynyl-containing SubPc 3 (Fig. 3) that was achieved by cyclotrimerization of 1,2-dicyanobenzene to afford chloro-subphthalocyanine 4. SubPc was later reacted with hydroquinone to afford hydroquinone-SubPc 5.3a The former was subsequently reacted with propargyl bromide to afford alkynyl- 
SubPc 3. Bioconjugation by peptide coupling required the synthesis of acid-containing SubPc synthon 6 (Fig. 2) that was synthesized from reaction of SubPcCl 4 with 4-nitrophenol to give 7. Nitro-SubPc 7 was reduced to afford amino-SubPc 8 that reacted with succinic anhydride to afford acid-SubPc 6 (CCDC 1456530). ${ }^{2 a}$ Several techniques were used to characterize SubPcs: the ${ }^{11} \mathrm{~B}-\mathrm{NMR}$ spectrum shows a singlet $(S=3 / 2)$, and ${ }^{1} \mathrm{H}-\mathrm{NMR}$ spectrum with multiplets around 8.0 and $8.8 \mathrm{ppm}$ corresponding to the signals of the indole moieties and the two doublets of the phenoxy moieties. Mass spectrometry analyses give for each SubPc the corresponding molecular peak $\left(\mathrm{M}+\mathrm{H}^{+}\right)$. The SubPc characteristic domed structure was observed in alkynyl-SubPc 3 crystallographic structure (Fig.3, S5). Optical properties of SubPc used for subsequent conjugation were examined by spectrometric and fluorimetric methods. The fluorescence quantum yield were in the range of that previously reported, i.e. $10 \%$ (Table 1.). ${ }^{3 a b}$

(ii) Cholesterol. The conjugation of BBN to the liposome was achieved either by peptide coupling or click chemistry. Hence, cholesterol, one component of the liposome was chemically modified to allow such a grafting (Fig 4.). To achieve coppercatalyzed or copper-free click chemistries, a series of amphiphilic cholesterol derivatives were synthesized as follows (Fig. 5): reaction of cholesterol with bromoacetylbromide afforded bromoester $\mathbf{9}$, which subsequently reacted with dimethylaminopropyne or 3azido-dimethylpropylamine 10 , to afford cholesteryl-ammonium species 11 (alkynyl) and $\mathbf{1 2}$ (azide), respectively. 3-Azidodimethylpropylamine $\mathbf{1 0}$ was synthesized from dimethylaminoethanol that underwent chlorodehydroxylation.

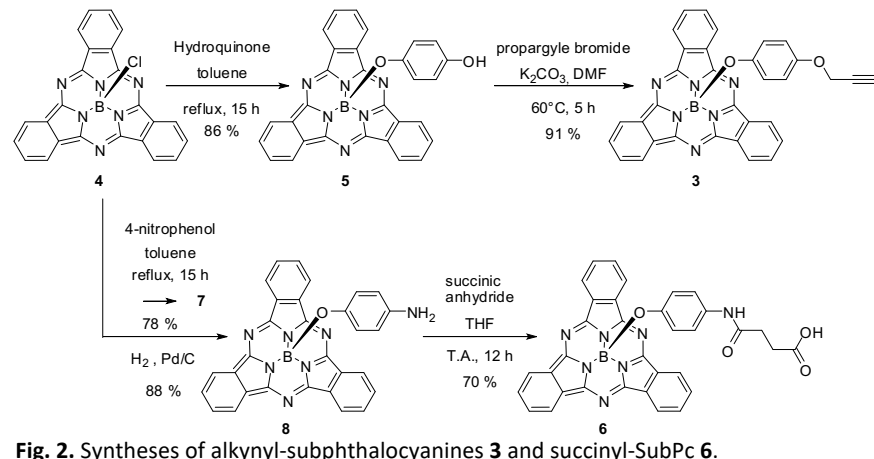

Fig. 2. Syntheses of alkynyl-subphthalocyanines $\mathbf{3}$ and succinyl-SubPc 6 .

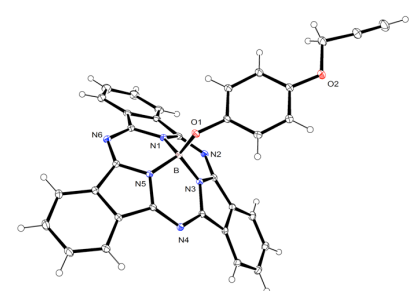

Fig. 3. X-ray diffraction structures of alkynyl-SubPc 3.
Table 1. Photophysical properties of functional SubPc

\begin{tabular}{|c|c|c|c|c|c|}
\hline \multicolumn{2}{|c|}{ Compound } & $\lambda_{\text {abs }} / \lambda_{\text {em }}(\mathrm{nm})$ & $\varepsilon\left(.10^{3} \mathrm{M}^{-1} \cdot \mathrm{cm}^{-1}\right)$ & $\varphi_{\mathrm{F}}^{[\mathrm{cc}]}$ & Ref \\
\hline 4 & SubPc-Cl[a] & $565 / 571$ & 101,2 & 0,25 & $3 a$ \\
\hline 7 & SubPc-NO ${ }_{2}^{[a]}$ & $563 / 572$ & 56,7 & 0,14 & $3 a$ \\
\hline 6 & SubPc-COOH[b] & $560 / 569$ & 52,8 & 0,07 & -- \\
\hline 3 & SubPc-CCH ${ }^{[a]}$ & $564 / 572$ & 52,3 & 0,10 & -- \\
\hline
\end{tabular}

[a] in chloroform. [b] in methanol. [c] $298 \mathrm{~K}$; Reference : rhodamine $6 \mathrm{G}$ in $\mathrm{MeOH}$ $\left(\phi_{F}=0,96, \lambda_{e x}=488 \mathrm{~nm}\right)$; All $\phi_{F}$ are corrected for changes in refractive index.

to afford 2-chloro-dimethylethylamine hydrochloride $13 \times \mathrm{HCl}$. This species was deprotonated to afford free-base species 13 , and was subsequently subjected to $\mathrm{SN}_{2}$ reaction upon treatment with sodium azide, to afford cholesterol-azide $\mathbf{1 0}$. Cholesterol derivatives were characterized by ${ }^{1} \mathrm{H}-\mathrm{NMR},{ }^{13} \mathrm{C}-\mathrm{NMR}$ and ESI-MS.

(iii) Bombesin. The syntheses of BBN were carried out on an automated solid phase peptide synthesizer as previously described, ${ }^{7 b}$ and were modified for BBN-azide and BBNbicyclononyne as follows (Fig. 6): BBN was elongated on a Rink amide MBHA resin by Fmoc-chemistry and its $\mathrm{N}$-terminus was subsequently deprotected by treatment with $20 \%$ piperidine in DMF. Coupling of N-(2-(2-(2-azidoethoxy)ethoxy))acetic acid to the peptidyl-resin afforded, after cleavage and deprotection, BBN-azide with an overall $36 \%$ yield. ${ }^{7 c}$ Similarly, the amine derivative $\mathbf{B B N}-\mathbf{N H}_{2}$ was prepared through the acylation of BBN supported on resin with the PEG-like spacer N-Fmoc (2-(2-

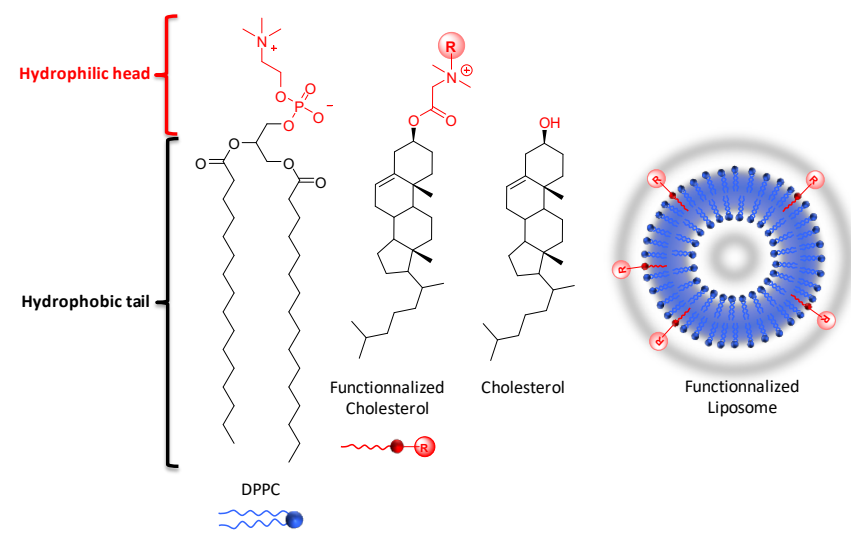

Fig. 4. Rationale for such syntheses: hydrophilic heads and hydrophobic tails found in two components of a liposome.

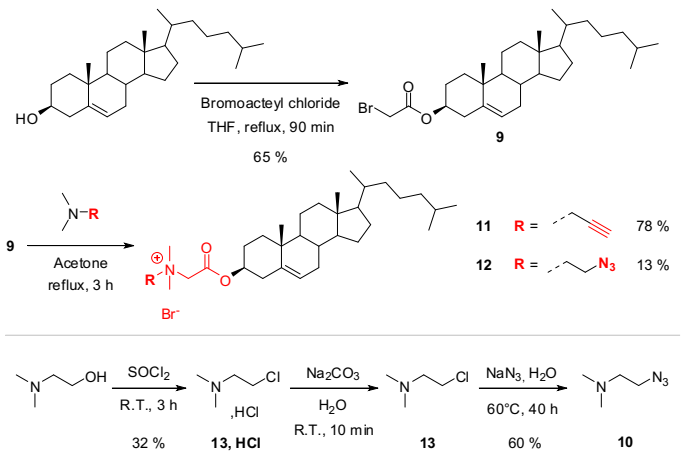

Fig. 5. Syntheses of azide- and alkynyl- cholesteryl derivatives. 


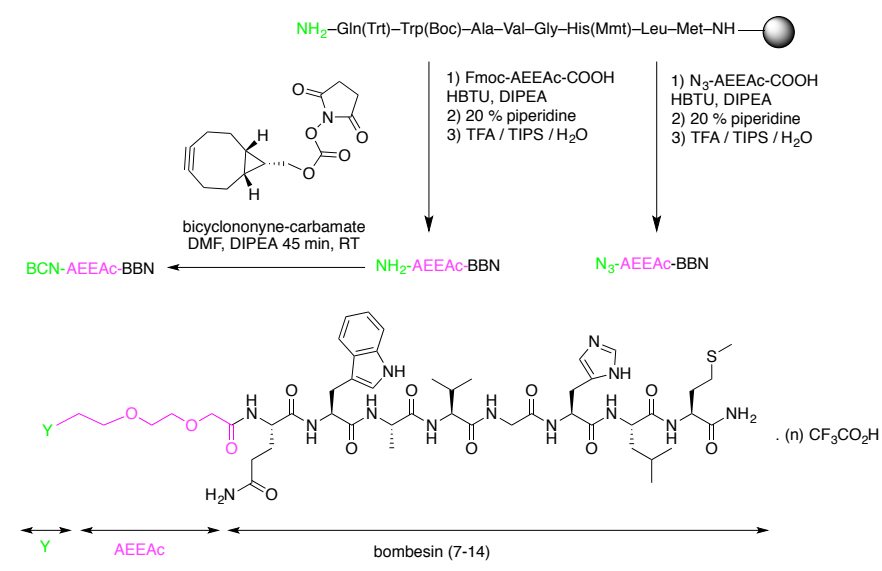

Fig. 6. Syntheses of PEG-terminated bombesin (7-14) terminated with $\mathrm{Y}=\mathrm{NH}_{2}, \mathrm{~N}_{3}$, and bi-cyclononyne, respectively.

(2-aminoethoxy)ethoxy))acetic acid, followed by the piperidinemediated deprotection of the $\mathrm{N}$-terminal Fmoc and the cleavage and deprotection of the peptide from the resin. Finally, the reaction of $\mathrm{BBN}-\mathrm{NH}_{2}$ with bicyclonyne- $\mathrm{N}$-succinimide carbonate in DMF afforded BBN-bicyclononyne in $66 \%$ yield after HPLC purification.

\section{Direct bioconjugation (probe-BBN conjugate)}

SubPc-alkyne $\mathbf{3}$ was reacted with BBN-bicyclononyne in homogeneous solution to afford SubPc-BBN bioconjugate $2 a$ that was purified by HPLC and obtained in $9 \%$ yield (Table 2, entry a). SubPc-BBN bioconjugate $\mathbf{2} \mathbf{b}$ was obtained in $\mathbf{7 \%}$ yield upon amide bond formation between carboxylic acid containing SubPc 6 and resin-bound amino-BBN (entry c). Subsequent removal of protecting groups and cleavage of SubPc-BBN from the resin was achieved to afford $\mathbf{2 b}$. Both SubPc conjugates were identified by mass spectroscopy (ESi-Q or MALDi-TOF), obtained with a $>87 \%$ purity (HPLC) and were soluble in water. However, over time it appeared that they slightly degrade in solution (an HPLC-MS analysis showed the appearance of new peaks, such as oxidation products, and UV analysis shows the decay of SubPc absorbance over time), possibly because of an intramolecular reaction between SubPc and a nucleophile in BBN. Such stability issues were observed previously, ${ }^{3 a}$ hence we decided to follow the protective approach by encapsulating SubPc in liposomes.
Indirect pre/post bioconjugation (liposome-BBN conjugate)

Indirect bioconjugation to SubPc means the conjugation of BBN to a liposome (Fig 1 and 7). Such a conjugation to a liposome is made possible by the availability of grafting functions on its outer face. At the molecular level, conjugation to a liposome means conjugation to its (alkyne- or azide-containing) cholesterol derivative component. Such a conjugation could be achieved before assembling the liposome, i.e on an isolated cholesterol: this is called the indirect pre-bioconjugation. Alternatively, the conjugation of BBN could be achieved on an already formed liposome that bears hanging grafting functions: this is called the indirect postbioconjugation. Whatever strategy used, a careful attention was given to the preparation of the liposome platform.

(i) Indirect post-bioconjugation strategy. Clickable azido- (or alkynyl-) liposomes were prepared by the injection method, ${ }^{3 a, 9}$ upon injecting organic solutions of phospholipid (DPPC), clickable cholesterol 11/12 (1:20 ratio), and the optical probe (SubPc 7) into vigorously stirred water or PBS (Fig. 8A). The resulting liposome suspension was subsequently purified by FPLC (Fast Protein Liquid Column Chromatography, i.e. steric exclusion chromatography) on a HiTrap desalting column (GEHealthcare): the fraction containing the liposome suspension was isolated at $\mathrm{t}=1 \mathrm{~min} / 4 \mathrm{~mL}$ (Fig. $8 \mathrm{C}$ ) (whereas unbound SubPc and cytotoxic traces of solvent (THF, chloroform) came later. The size of the vesicles was determined by DLS ( $d_{\mathrm{DLS}}=$ $57 \mathrm{~nm})$, TEM $\left(\mathrm{d}_{\text {TEM }}=60 \mathrm{~nm}\right)$. Stability of the vesicles over time was monitored by DLS: it appeared to be stable after $48 \mathrm{~h}$, especially for alkynyl-liposomes (Fig. 8E). The purified suspension of vesicles (with no un-encapsulated SubPc left) was examined by UV/Vis: it showed the characteristic bands of SubPc, with more resolution than in a solvent-water mixture as an indication of entrapment (Fig. 9B-D). When the preparation of liposomes was carried out upon injecting the organic solution in water, liposomes were not stable. This is unlike in buffer, where liposomes were stable.

Subsequent conjugation of functionalized liposome was carried out on a pure sample of azide-liposome (containing the azide steroid 12). The liposome was subjected to copper-free click chemistry in the presence of BBN-cyclooctyne (Fig.9). The progress of the reaction was monitored by MALDI-TOF analysis, from a lyophilized aliquot of the liposome suspension, until no trace of free BBN was found $(t=24 \mathrm{~h})$ $\begin{aligned} \text { SubPc }+ \text { BBN } & \rightarrow \text { SubPc-BBN (2ab) } \\ \text { Chol }+ \text { BBN } & \rightarrow \text { Chol-BBN (1ab) }\end{aligned}$

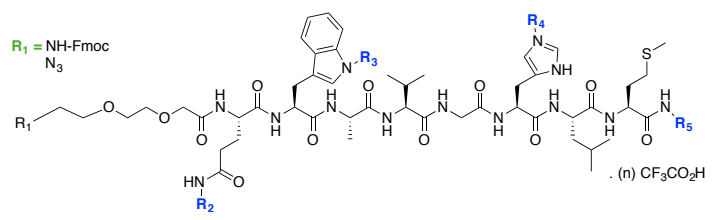




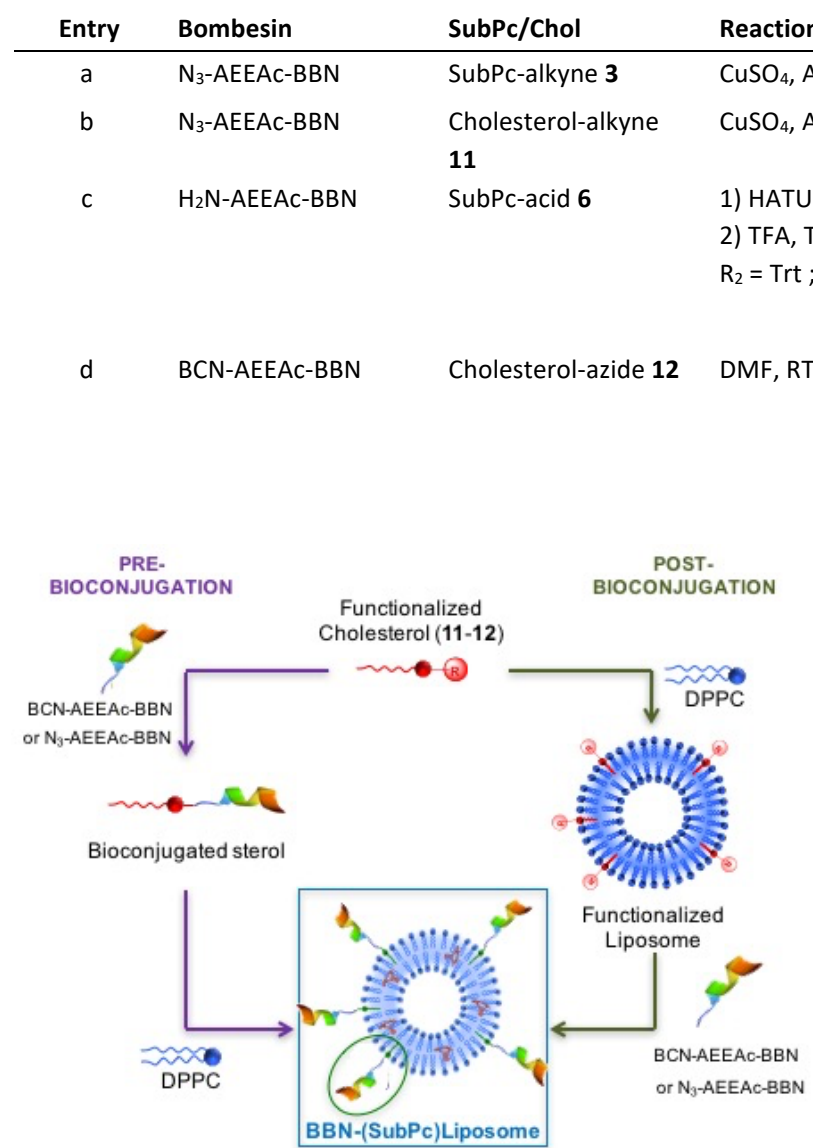

Fig. 7. Pre- and post-bionconjugation approaches for the preparation of functionalized liposomes.

A
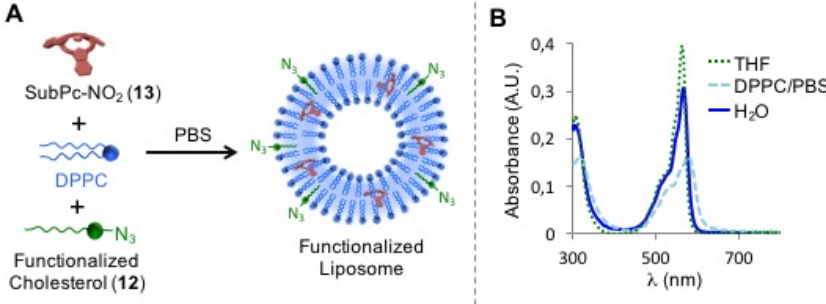

C

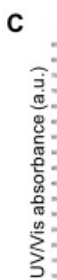
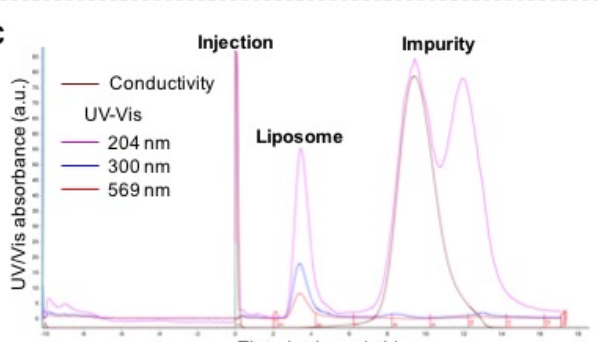

Eluted volume $(\mathrm{mL})$

D
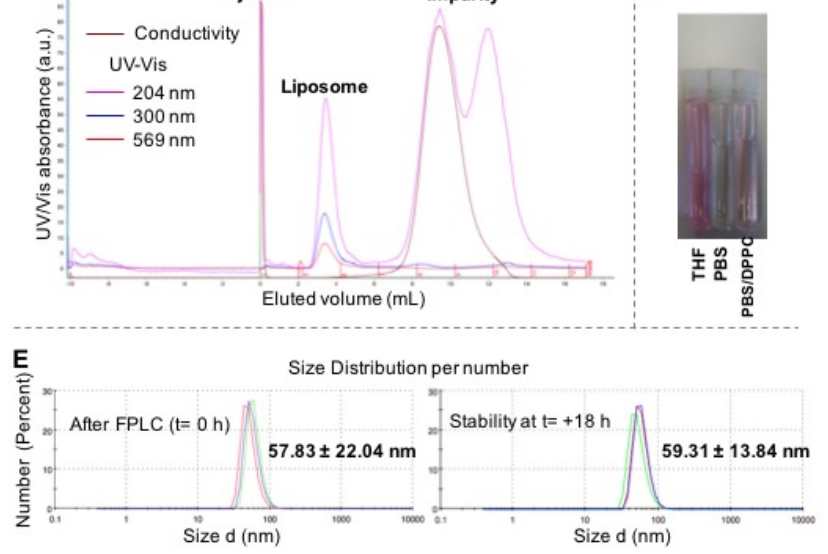

(ii) Indirect pre-bioconjugation strategy (Fig. 7, Table 1) consisted in replacing Cholesterol-BBN conjugates $\mathbf{1 a}$ or $\mathbf{1 b}$ instead of cholesterol-azide 12 (or cholesterol-alkyne 11) in the PBS mixture to afford the BBN-conjugated liposome.

Hence, the pre-bioconjugation strategy started from the grafting of the biomolecule to one liposome's component (i.e. cholesterol additive), prior to the preparation of the liposome to afford BBNCholesterol conjugates 1ab. The conjugation of BBN-azide with cholesteryl-alkyne 11 (1 equiv.) (i.e. pre-functionalization by copper-catalyzed click chemistry) was carried out in the presence of copper sulphate (1.1 equiv.) and sodium ascorbate as the reducing agent ( 3 equiv.)(table 2 , entry b). Alternatively BBN-bicyclononyne and cholesteryl-azide $\mathbf{1 1}$ were reacted without $\mathrm{Cu}$ catalyst, for $4 \mathrm{~h}$ to afford 1b (entry d). BBN-cholesterol conjugates 1ab were purified by semi-preparative HPLC (purity > 93\%). Upon liposome formation starting from $1 \mathrm{ab}$ a follow-up by DLS showed that various sizes were obtained. Also, it appeared that the targeted functionalized liposome degraded on the Hi-Trap column as a result of elution using water instead of a buffer (another buffer than PBS). When the liposome was prepared from a sterol-BBN bioconjugate subsequent DLS analyses showed the formation of large vesicles (500-1500 nm), which does not correspond to a homogeneous system as found in a postbioconjugation approach. Hence the later appeared to be the best approach.

\section{Validation of Conjugates: affinity studies.}

The affinity of the cholesterol-BBN conjugate $\mathbf{1 b}$ for the BBN receptors was measured on a competitive binding assay on rat cerebral cortex membranes. ${ }^{11}$ This bioconjugate displaced [125I][Tyr $\left.{ }^{4}\right]$ bombesin (1-14) radioligand (the $K_{\mathrm{D}}$ of which is $0.71 \mathrm{nM}$ ) with an IC $\mathrm{C}_{50}$ of displacement of $13.9 \mathrm{nM}$ (Fig. 10). Compared to bombesin (1-14), the reference compound, which has an $\mathrm{IC}_{50}$ of displacement of $0.28 \mathrm{nM}$, the $\mathrm{IC}_{50}$ found for $\mathbf{1 b}$ corresponds to a 66 -fold loss of inhibitory activity. Despite such a loss, the affinity may remain sufficient to consider future in vitro studies. Also, such a value still compares well with values reported for other studies. ${ }^{12}$ Future in vitro studies will focus on the evaluation of BBN conjugates on cell overexpressing BBN receptors and subsequent imaging studies. 


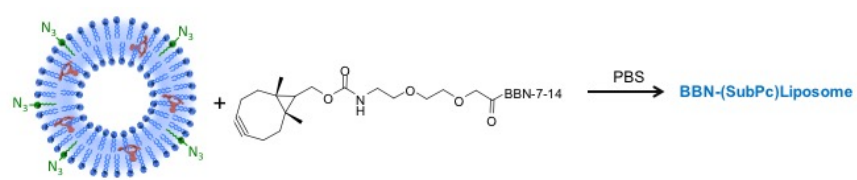

Fig. 9. Representation of a post-bioconjugation step on a $\mathrm{N}_{3}$-liposome (containing SubPc 7) by copper-free click chemistry with BBN-bicyclononyne.

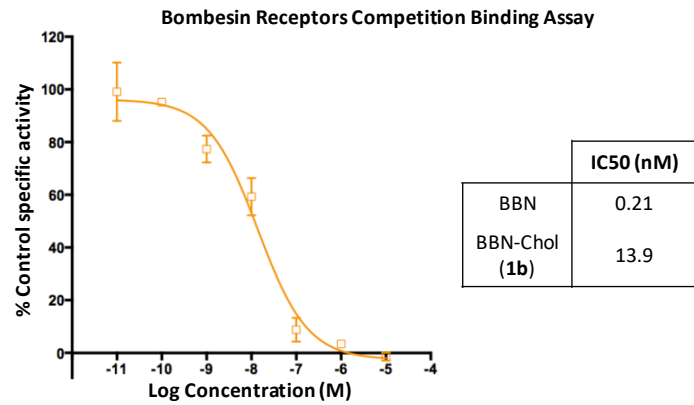

Fig. 10. BBN-Liposome conjugates: $I_{50}$ Binding Studies for cholesterol-liposome conjugate $\mathbf{1 b}$

\section{Conclusions}

Two general approaches were chosen for the conjugation to BBN. The covalent attachment of BBN to SubPc (direct bioconjugation) through robust amide or triazole bonds was achieved in modest yields. ${ }^{7}$ Moreover, the resulting conjugate was intrinsically unstable because of the slow reactivity of SubPc against nucleophiles and the moderate solubility in water. Hence, the alternative encapsulation approach in a liposome appeared appropriate to offer the necessary protection of SubPc against these species. Subsequent grafting of the biomolecule to the liposome encapsulating non graftable SubPc was then considered (indirect bioconjugation). As a result one component of the liposome was chemically modified to append a function on the outer face of the nanoparticle that made click-chemistry with a BBN derivative possible. Copper-free click chemistry was preferred to copper-catalyzed click chemistry, because it is faster and the toxicity of copper is prevented. Liposomes were purified at various stages and a monitoring of the stability was achieved. The affinity of the BBN-cholesteryl derivative for bombesin receptors was still acceptable. Future studies will focus on in vitro cell imaging and in vivo tumor imaging, not before having tested (DLS, FPLC, drug release) the stability and integrity of a suspension of such liposome constructs against potentially not liposome-friendly conditions, albeit physiologically relevant to cancer (salinity, presence of various macromolecules, $\mathrm{pH}$ etc).

Overall, this study reminded that liposomes are a second chance for fluorophores, drugs, contrast agents that are not water-soluble to be handled in aqueous physiological media, as we have shown before. ${ }^{3 a, 9 a, 9 c}$ Encapsulation is also a strategy to protect sensitive molecules, such as SubPc, against exogenous reactive molecules or even water. ${ }^{3 a}$ The actual study specifically showed that azido- or alkynyl-liposomes are a convenient entry point for a bioconjugation/biovectorization approach (on the outer face of the liposome), which basically offers a second chance to fluorophores (and by extension drugs, contrast agents) with no reactive functional group available on their backbone to pretend to achieve (indirect) bioconjugation with a biomolecule (i.e. an indirect approach offered to achieve future site-specific targeting of tumors).

\section{Experimental Section}

Materials.

Reagents and solvents were from various suppliers. They were used as as received without any further purification when no otherwise stated. Subphtalocyanine $\mathbf{4}, \mathbf{7}$ and $\mathbf{8}$ were synthesized as we previously described (ref 3a).

\section{Instrumentation.}

NMR and Mass Spectrometry analyses were carried out at the "Plateforme d'Analyses Chimiques et de Synthèse Moléculaire de l'Université de Bourgogne" (PACSMUB). ${ }^{1} \mathrm{H}$ NMR spectra (300 MHz), and ${ }^{13} \mathrm{C}$ NMR spectra $(75 \mathrm{MHz})$, were recorded on Bruker 300 Avance III, II spectrometers, respectively. Chemical shifts are quoted in parts per million ( ) relative to tetramethylsilane, TMS $\left({ }^{1} \mathrm{H}\right.$ and $\left.{ }^{13} \mathrm{C}\right)$, using the residual protonated solvent $\left({ }^{1} \mathrm{H}\right)$ or the deuterated solvent $\left({ }^{13} \mathrm{C}\right)$ as an internal standard (residual chloroform from deuterated chloroform chemical shift was set at $7.26 \mathrm{ppm}$ and deuterated dimethylsufoxyde at $2.50 \mathrm{ppm}$ ). Coupling constants are reported in Hertz. The following abbreviations were used to describe spin multiplicity: $\mathrm{s}=$ singlet, $\mathrm{d}=$ doublet, $\mathrm{t}=$ triplet, $\mathrm{m}$ = multiplet. The identity of established using high-resolution mass spectrometry and multinuclear NMR spectroscopy. The standard mass was performed on Ultraflex II LRF 2000 (BRUKER), using dithranol or DHB as a matrix. The exact mass of the complexes was obtained on a Thermo LTQ Orbitrap XL ESI-MS. DLS measurements were performed on a

UV-Vis spectra were performed on a Shimadzu UV-2550 spectrophotometer, in a solvent of choice (DCM, THF, MeOH, DMSO, water) in glass cuvettes $1 \times 1 \times 3 \mathrm{~cm}(1 \mathrm{~cm}$ path).

Fluorescence measurements were performed on a Jasco FP-8500 spectrofluorometer equipped with a Xe source. Fluorescence quantum yields were calculated using Rhodamine $6 \mathrm{G}$ in methanol as reference $\left(\Phi_{F}=0.94\right)$. Excitation was performed at $488 \mathrm{~nm}$ for both sample and reference. Emission spectrums were recorded for an absorbance at $488 \mathrm{~nm}$ comprise between 0.03 and 0.07 . Fluorescence quantum yields $\left(\Phi_{\mathrm{F}}\right)$ were determinate by the comparison method, using the following equation:

$$
\phi_{F}=\phi_{F}(S t d) \times\left(\frac{\eta}{\eta(S t d)}\right)^{2} \times\left(\frac{1-10^{-A b s}}{1-10^{-A b s(S t d)}}\right) \times\left(\frac{A(S t d)}{A}\right)
$$

With:

Std correspond to standard (Rhodamine 6G)

$\Phi_{\mathrm{F}}$ and $\Phi_{\mathrm{F}}(\mathrm{Std})$ : fluorescence quantum yields 
$\eta$ and $\eta(S t d)$ : refractive indices of solvent ( $\mathrm{MeOH}$ for standard; DCM, DMF or water for samples)

Abs and $\mathrm{Abs}(\mathrm{Std})$ : absorbances at excitation wavelength (488 $\mathrm{nm}$ )

$A$ and $A(S t d)$ : areas under the fluorescence curves

HPLC. Compounds were analyzed on a Dionex Ultimate 3000 HPLC system. The methods used were the following: Method A: Column: Chromolith High Resolution RP-18 $(5 \times 4.6 \mathrm{~mm})$; Eluent $\mathrm{A}: \mathrm{CH}_{3} \mathrm{CN}+0.1 \%$ TFA; eluent $\mathrm{B}: \mathrm{H}_{2} \mathrm{O}+0.1 \%$ TFA. Flow: $3 \mathrm{~mL} / \mathrm{min}$. Equilibrate for $1.75 \mathrm{~min}$; afterwards, gradient from $100 \%$ B to $100 \%$ A; duration: 5 min; keep constant for $1 \mathrm{~min}$; return in $1.5 \mathrm{~min}$ to initial conditions. UV detectors: $214 \mathrm{~nm}$, $230 \mathrm{~nm}, 254 \mathrm{~nm}, 565 \mathrm{~nm}$. Method B: Column: Kinetex 26_um C18 100A (50×2,1 mm); Eluent A: $\mathrm{CH}_{3} \mathrm{CN}+0.1 \%$ TFA; eluent B: $\mathrm{H}_{2} \mathrm{O}+0.1 \%$ TFA. Flow: $0.5 \mathrm{~mL} / \mathrm{min}$. Equilibrate for $1.75 \mathrm{~min}$ afterwards; ramp from $95 \%$ B to $5 \% \mathrm{~A}$; duration: 5 min; keep constant for $1.5 \mathrm{~min}$; return in $1.5 \mathrm{~min}$ to initial conditions. UV detectors: $214 \mathrm{~nm}, 230 \mathrm{~nm}, 254 \mathrm{~nm}$.

X-ray diffraction (XRD) data were collected at room temperature for 24 hours using a Siemens D5000 automatic powder diffractometer, operating at $35 \mathrm{~mA}$ and $50 \mathrm{kV}$. The lattice parameters and the crystallite size $\left(\varnothing_{\mathrm{XRD}}\right)$ calculations were obtained using the Topas software from Bruker.

\section{Liposomes.}

Preparation. Liposomes were prepared by the injection method according to our reported procedure (3a) and adapted as follows. $100 \mu \mathrm{L}$ of each of the following solutions were taken: a) A solution of DPPC in ethanol ( $21 \mathrm{mM})$ b) a solution of cholesterol or cholesteryl-ammonium in ethanol ( $3 \mathrm{mM}) \mathrm{d}$ ) a solution of nitrosubphthalocyanine 7 in chloroform (0.5 mM). Overall $300 \mu \mathrm{L}$ of solutions was quickly injected using an Hamilton syringe in $10 \mathrm{~mL}$ of buffer solution (PBS or $\mathrm{NaCl}$ ) under vigourous agition at $60^{\circ} \mathrm{C}$.. The mixture was left under agitation during $2 \mathrm{~min}$ at the same temperature, then cooled down to room temperature. Subsequently this suspension may be filtered through $0.2 \mu \mathrm{m}$ filters.

Purification. The purification of the liposomes was achieved on a Äkta pure (GE). The liposome suspension (500 L) was injected on a $1 \mathrm{~mL}$ loop, and elution was performed on a $\mathrm{Hi}$ trap column (GE) using water as the eluent with a flow rate set at $3 \mathrm{~mL} / \mathrm{min}$. The detection wavelengths were set at $204 \mathrm{~nm}$, $300 \mathrm{~nm}$, and $580 \mathrm{~nm}$. Upon collection of fractions, $4 \mathrm{~mL}$ of suspension were collected, and subsequently lyophilized.

Characterization. DLS (Dynamic Light Scattering) Hydrodynamic diameter measurements were performed on a Zeta-Nanosizer (Malvern) into $10^{-2} \mathrm{M} \mathrm{NaCl}$ solutions.

Competitive Binding Assays were carried out by Cerep.

\section{Conjugation of liposome with BBN.}

To the previously prepared liposomial solution was added $\mathrm{N}$ (2-(2-(2-(N-4-(((bicyclo[6.1.0]non-4-yn-9-ylmethoxy)carbonyl) amino) ethoxy)ethoxy))acetyl-bombesin(7-14)) (1.42 mg, 0.45 $\mu \mathrm{mol}, 3 \mathrm{eq})$ and the solution was stirred at room temperature for $18 \mathrm{~h}$. The mixture was lyophilized and subjected to MALDITOF MS analysis to confirm the success of the reaction. MS
MALDI-TOF: $\mathrm{m} / \mathrm{z}=1801.84[\mathrm{M}-\mathrm{Br}]^{+}$(calcd for $\mathrm{C}_{93} \mathrm{H}_{145} \mathrm{~N}_{18} \mathrm{O}_{16} \mathrm{~S}^{+}$: 1802.08).

\section{Synthesis}

Cholesterol-BBN-7-14 (1a) (copper catalyzed click chemistry coupling method). A mixture of $\mathrm{N}-(2-(2-(2-)(\mathrm{N}-$ azidoethoxy)ethoxy))acetyl-bombesin(7-14)) $\quad(5.76 \quad \mathrm{mg}, \quad 4.7$ $\mu \mathrm{mol})$, alkyne containing cholesterol derivative $11(2.78 \mathrm{mg}$, $4.7 \mu \mathrm{mol})$, copper sulfate $(0.83 \mathrm{mg}, 5.2 \mu \mathrm{mol})$ and sodium ascorbate $(2.79 \mathrm{mg}, 14.1 \mu \mathrm{mol})$ in $350 \mu \mathrm{L}$ of DMF was stirred at room temperature for $8 \mathrm{~h}$. The peptide was purified by semipreparative RP-HPLC (C18, eluent: $\mathrm{CH}_{3} \mathrm{CN}+0.1 \%$ TFA / $\mathrm{H}_{2} \mathrm{O}+$ $0.1 \%$ TFA, gradient from $70: 30$ to $100: 0 \mathrm{v} / \mathrm{v}$ in $40 \mathrm{~min}$, Rt= $17.18 \mathrm{~min}$ ), and pure fractions were collected and lyophilized to give the desired product $(2.5 \mathrm{mg}, 31 \%)$. MS ESI: $\mathrm{m} / \mathrm{z}=$ $1620.14[\mathrm{M}-\mathrm{Br}]^{+}$(calcd for $\mathrm{C}_{83} \mathrm{H}_{130} \mathrm{~N}_{17} \mathrm{O}_{14} \mathrm{~S}^{+}:$1620.97). HPLC $(\operatorname{method} \mathrm{B}): \operatorname{Rt}(\min )=5.73(90.8 \%$ at $254 \mathrm{~nm})$.

Cholesterol-BBN-7-14 (1b) (copper free click chemistry coupling method). N-(2-(2-(2-(N- 4-(()bicyclo[6.1.0]non-4-yn9-ylmethoxy)(arbonyl)amino) ethoxy)ethoxy))acetylbombesin(7-14)) $(5.20 \mathrm{mg}, 4.11 \mu \mathrm{mol})$ and cholesterol derivative $12(2.04 \mathrm{mg}, 3.28 \mu \mathrm{mol})$ were put in $750 \mu \mathrm{L}$ of DMF. The mixture was stirred at room temperature for $15 \mathrm{~h}$. The peptide was purified by semi-preparative RP-HPLC (C18, eluent: $\mathrm{CH}_{3} \mathrm{CN}+0.1 \%$ TFA $/ \mathrm{H}_{2} \mathrm{O}+0.1 \%$ TFA, gradient from $70: 30$ to $100: 0 \mathrm{v} / \mathrm{v}$ in $40 \mathrm{~min}, \mathrm{Rt}=17.25 \mathrm{~min}$ ), and pure fractions were collected and lyophilized to afford the desired product ( $2.3 \mathrm{mg}, 32 \%$ ). MS MALDI-TOF: $\mathrm{m} / \mathrm{z}=1802.26[\mathrm{M}-\mathrm{Br}]^{+}$ (calcd for $\mathrm{C}_{93} \mathrm{H}_{145} \mathrm{~N}_{18} \mathrm{O}_{16} \mathrm{~S}^{+}$: 1802.08). HPLC (method B): Rt $(\min )=5.81(92.80 \%$ at $254 \mathrm{~nm})$.

SubPc-BBN-7-14 (2a) (click chemistry coupling method). ( $\mathrm{N}-(2-$ (2-(2-(N-azidoethoxy)ethoxy))acetyl-bombesin(7-14)) (15 mg, $12 \mu \mathrm{mol})$, SubPc-CCH $3(6.73 \mathrm{mg}, 12 \mu \mathrm{mol})$, copper sulfate ( $3.41 \mathrm{mg}, 14 \mu \mathrm{mol})$ and sodium ascorbate $(7.38,37 \mu \mathrm{mol})$ were mixed together in $100 \mu \mathrm{L}$ of DMF. The reaction mixture was stirred at room temperature for $30 \mathrm{~min}$, then the solution was directly purified by semi-preparative RP-HPLC (C18, eluent: $\mathrm{CH}_{3} \mathrm{CN}+0.1 \%$ TFA / $\mathrm{H}_{2} \mathrm{O}+0.1 \%$ TFA, gradient from 35:65 to $65: 35 \mathrm{v} / \mathrm{v}$ in $40 \mathrm{~min}, \mathrm{Rt}=27.1 \mathrm{~min}$ ), and pure fractions were collected and lyophilized to give SubPc-BBN-7-14 conjugate $2 \mathrm{a}$ as a pink solid (1.45 mg, $7 \%$ ). MS MALDI-TOF: $\mathrm{m} / \mathrm{z}=1675.77$ $[\mathrm{M}+\mathrm{Na}]^{+}$(calcd for $\mathrm{C}_{82} \mathrm{H}_{93} \mathrm{BN}_{22} \mathrm{O}_{14} \mathrm{SNa}^{+}:$1676.62). HPLC $(\operatorname{method} A):$ Rt $(\min )=3.07(87.90 \%$ at $254 \mathrm{~nm} ; 89.08 \%$ at 565 $\mathrm{nm})$.

SubPc-BBN-7-14 (2b) (peptide coupling method). Rink Amide MBHA resin grafted ( N- $(2-(2-)(2-(\mathrm{N}-$ fmoc)aminoethoxy)ethoxy))acetyl-(His(N-Mtt)-Trp(N-Boc)$\mathrm{G} \ln (\mathrm{N}-\mathrm{Trt}))$ bombesin(7-14)) (66.4 mg, $0.25 \mathrm{mmol} / \mathrm{g}, 16.6 \mu \mathrm{mol})$ was dissolved in $1 \mathrm{~mL}$ of DMF and stirred at room temperature for $30 \mathrm{~min}$, then filtered off and washed with DMF $(2 \mathrm{~mL})$. The solid was resuspended in $20 \%$ piperidine in DMF $(1 \mathrm{~mL})$ for 10 $\min$ (twice) to deprotect the amino group, then washed with DMF $(2 \times 2 \mathrm{~mL}), \mathrm{DCM}(2 \times 2 \mathrm{~mL}), \mathrm{MeOH}(2 \mathrm{~mL}), \mathrm{DCM}(1 \mathrm{~mL})$ and DMF $(1 \mathrm{~mL})$. Then SubPc-COOH 6 (15 mg, $12.5 \mu \mathrm{mol})$, HATU (9.47 mg, $24.9 \mu \mathrm{mol}$ ) and DIPEA (4.33 $\mu \mathrm{L}, 24.9 \mu \mathrm{mol})$ were added and the solution was made up with DMF to obtain a total volume of $1 \mathrm{~mL}$. The reaction mixture was stirred at room 
temperature for $90 \mathrm{~min}$, then the solid was washed with DMF $(2 \times 2 \mathrm{~mL}), \mathrm{DCM}(2 \times 2 \mathrm{~mL}), \mathrm{MeOH}(2 \mathrm{~mL}), \mathrm{DCM}(1 \mathrm{~mL})$ and DMF $(1 \mathrm{~mL})$. The peptide was cleaved from the resin with simultaneous removal of the side-chain protecting groups by treatment with $1 \mathrm{~mL}$ of TFA/TIPS/water mixture (95/2.5/2.5 $\mathrm{v} / \mathrm{v}$ ) for $90 \mathrm{~min}$ at room temperature. The filtrate from the cleavage mixture was concentrated, precipitated in cold Et2O and collected by centrifugation (twice), and lyophilized to afford crude peptide. The peptide was purified by semipreparative RP-HPLC (C18, eluent: $\mathrm{CH}_{3} \mathrm{CN}-0.1 \%$ TFA / $\mathrm{H}_{2} \mathrm{O}-0.1 \%$ TFA, gradient from 30:70 to $60: 40 \mathrm{v} / \mathrm{v}$ in $30 \mathrm{~min}, \mathrm{Rt}=20.7 \mathrm{~min}$ ), and pure fractions were collected and lyophilized to give SubPc-BBN-7-14 conjugate $\mathbf{2 b}$ as a pink solid ( $2.5 \mathrm{mg}, 9 \%$ ). MS ESI: $m / z=1671.62[\mathrm{M}+\mathrm{H}]^{+}$(calcd for $\mathrm{C}_{84} \mathrm{H}_{97} \mathrm{BN}_{21} \mathrm{O}_{15} \mathrm{~S}^{+}: 1670.73$ ), $1692.67[\mathrm{M}+\mathrm{Na}]^{+}$(calcd for $\mathrm{C}_{84} \mathrm{H}_{96} \mathrm{BN}_{21} \mathrm{O}_{15} \mathrm{SNa}^{+}$: 1692.71). HPLC $(\operatorname{method} A):$ Rt $(\min )=2.95(88.2 \%$ at $254 \mathrm{~nm} ; 92.3 \%$ at 565 $\mathrm{nm})$.

B-(4-(3-carboxypropanamido)phenoxy)[subphthalocyaninato] boron(III) (6). To a solution of SubPc 8 (100 mg, $0.2 \mathrm{mmol})$ in THF $(5 \mathrm{~mL})$ was added succinic anhydride $(30 \mathrm{mg}, 0.3 \mathrm{mmol})$. The reaction mixture was stirred at room temperature for 12 $h$, then evaporated to dryness. The resulting residue was resuspended in $5 \mathrm{~mL}$ of methanol and precipited off by addition of water $(20 \mathrm{~mL})$, filtered off and washed with a 1:3 $\mathrm{MeOH} / \mathrm{H}_{2} \mathrm{O}$ mixture $(3 \times 20 \mathrm{~mL})$, then subjected to silica gel column chromatography (eluent: $\mathrm{DCM} / \mathrm{MeOH} 95: 5$ ) and finally dried under reduced pressure to afford compound $14(84 \mathrm{mg}$, $70 \%) .{ }^{1} \mathrm{H}$ NMR $\left(300 \mathrm{MHz}, \mathrm{DMSO}-\mathrm{d}_{6}, 300 \mathrm{~K}\right): \delta(\mathrm{ppm})=2.40(\mathrm{~m}$, $4 \mathrm{H}) ; 5.24(\mathrm{~d}, 3 \mathrm{~J}=8.8 \mathrm{~Hz}, 2 \mathrm{H}) ; 6.93(\mathrm{~d}, 3 \mathrm{~J}=8.8 \mathrm{~Hz}, 2 \mathrm{H}) ; 8.00(\mathrm{~m}$, $6 \mathrm{H}) ; 8.84(\mathrm{~m}, 6 \mathrm{H}) ; 9.59(\mathrm{~s}, 1 \mathrm{H}) ; 11.55$ (s broad, 1H). HR-MS ESI: $\mathrm{m} / \mathrm{z}=604.19160[\mathrm{M}+\mathrm{H}]^{+}$(calcd for $\mathrm{C}_{34} \mathrm{H}_{23} \mathrm{BN}_{7} \mathrm{O}_{4}{ }^{+}: 604.19050$ ); 602.17502 [M-H] (calcd for $\mathrm{C}_{34} \mathrm{H}_{21} \mathrm{BN}_{7} \mathrm{O}_{4}:$ : 602.17485). HPLC $(\operatorname{method} A)$ : Rt $(\min )=2.94(94.0 \%$ at $254 \mathrm{~nm} ; 98.5 \%$ at 565 $\mathrm{nm})$. UV-Vis $(\mathrm{MeOH}): \lambda \max (\mathrm{nm})\left(\varepsilon \times 10^{3} \mathrm{~L} \cdot \mathrm{mol}^{-1} \cdot \mathrm{cm}^{-1}\right)=302$ (26.5), 560 (52.8).

B-(4-hydroxyphenoxy)[subphthalocyaninato]boron(III) (5). A mixture of $B$-chloro[subphthalocyaninato]boron(III) 3 (50 mg, $0.12 \mathrm{mmol}$ ) and hydroquinone (256 $\mathrm{mg}, 1.2 \mathrm{mmol}$ ) in toluene $(5 \mathrm{~mL})$ was heated under reflux for $15 \mathrm{~h}$. Upon evaporation of the solvent, the residue was subjected to alumina gel column chromatography (eluent: $\mathrm{DCM} / \mathrm{MeOH}$ 99: 1) and then to silica gel column chromatography (eluant: $\mathrm{DCM} / \mathrm{MeOH} 98: 2$ ) and dried under reduced pressure (100 mg, $86 \%)$. ${ }^{1} \mathrm{H}$ NMR (300 $\left.\mathrm{MHz}, \mathrm{CDCl}_{3}, 300 \mathrm{~K}\right): \delta(\mathrm{ppm})=5.32(\mathrm{~d}, 3 \mathrm{~J}=8.8 \mathrm{~Hz}, 2 \mathrm{H}) ; 6.28(\mathrm{~d}$, $3 \mathrm{~J}=8.8 \mathrm{~Hz}, 2 \mathrm{H}) ; 7.92(\mathrm{~m}, 6 \mathrm{H}) ; 8.86(\mathrm{~m}, 6 \mathrm{H})$. HR-MS ESI: $\mathrm{m} / \mathrm{z}=$ $503.1446[\mathrm{M}-\mathrm{H}]^{-}$(calcd for $\mathrm{C}_{30} \mathrm{H}_{16} \mathrm{BN}_{6} \mathrm{O}_{2}{ }^{-}:$503.1428). UV-Vis (DCM): $\lambda_{\max }(\mathrm{nm})\left(\varepsilon \times 10^{3}\right.$ L.mol $\left.{ }^{-1} . \mathrm{cm}^{-1}\right)=304$ (29.5), 563 (61.2).

\section{B-(4-propargyloxyphenoxy)[subphthalocyaninato]boron(III) (3).}

To a solution of compound 5 (50 $\mathrm{mg}, 0.1 \mathrm{mmol}$ ) and potassium carbonate $(25.5 \mathrm{mg}, 0.2 \mathrm{mmol})$ in $5 \mathrm{~mL}$ of DMF was added propargyl bromide $(10.7 \mu \mathrm{L}, 0.1 \mathrm{mmol})$. The mixture was left at $60^{\circ} \mathrm{C}$ for $5 \mathrm{~h}$, then filtered off on clarcel $^{\circ}$ and evaporated to dryness under reduced pressure. The product was subjected to silica gel column chromatography (eluent: $\mathrm{DCM} / \mathrm{MeOH}$ 98:2 vol.) and dried under reduced pressure (49 mg, $91 \%) .{ }^{1} \mathrm{H}$ NMR $\left(300 \mathrm{MHz}, \mathrm{CDCl}_{3}, 300 \mathrm{~K}\right): \delta(\mathrm{ppm})=2.39(\mathrm{t}, 4 \mathrm{~J}=2.4 \mathrm{~Hz}, 1 \mathrm{H}) ; 4.42$ $\left(\mathrm{d},{ }^{4} \mathrm{~J}=2.4 \mathrm{~Hz}, 2 \mathrm{H}\right) ; 5.34\left(\mathrm{~d},{ }^{3} \mathrm{~J}=9.0 \mathrm{~Hz}, 2 \mathrm{H}\right) ; 6.37\left(\mathrm{~d},{ }^{3} \mathrm{~J}=9.0 \mathrm{~Hz}\right.$, $2 \mathrm{H}) ; 7.90(\mathrm{~m}, 6 \mathrm{H}) ; 8.84(\mathrm{~m}, 6 \mathrm{H})$. MS MALDI-TOF: $\mathrm{m} / \mathrm{z}=543.02$ $[\mathrm{M}+\mathrm{H}]^{+}$(calcd for $\mathrm{C}_{33} \mathrm{H}_{20} \mathrm{BN}_{6} \mathrm{O}_{2}$ : 543.17). HR-MS ESI: $\mathrm{m} / \mathrm{z}=$ $543.1752[\mathrm{M}+\mathrm{H}]^{+}$(calcd for $\mathrm{C}_{33} \mathrm{H}_{20} \mathrm{BN}_{6} \mathrm{O}_{2}{ }^{+}:$543.1741). UVVis $(D C M): \lambda_{\max }(\mathrm{nm})\left(\varepsilon \times 10^{3}\right.$ L. mol-1.cm $\left.{ }^{-1}\right)=302(28.2), 564$ (52.3).

Cholesteryl bromoacetate (9). To a solution of cholesterol (1g, $2.56 \mathrm{mmol})$ in distilled THF $(15 \mathrm{~mL})$ was slowly added bromoacetyl chloride $(654 \mu \mathrm{L}, 7.77 \mathrm{mmol})$ under nitrogen atmosphere. The reaction mixture was heated to reflux for 1.5 $h$, then concentrated under vacuum. The oil obtained was dissolved in refluxing ethyl acetate, then left at room temperature for several hours. The crystals formed were filtered off, washed with ethyl acetate and dried under reduced pressure to yield cholesteryl bromoacetate 9 as a white crystalline powder (855 mg, $65 \%) .{ }^{1} \mathrm{H}$ NMR (300 MHz, $\left.\mathrm{CDCl}_{3}, 300 \mathrm{~K}\right): \delta(\mathrm{ppm})=0.68(\mathrm{~s}, 3 \mathrm{H}) ; 0.86-1.70(\mathrm{~m}, 34 \mathrm{H}) ; 1.75-$ $2.07(\mathrm{~m}, 4 \mathrm{H}) ; 2.36(\mathrm{~d}, 3 \mathrm{~J}=7.8 \mathrm{~Hz}, 2 \mathrm{H}) ; 3.80(\mathrm{~s}, 2 \mathrm{H}) ; 4.67(\mathrm{~m}, 1 \mathrm{H})$; $5.39\left(\mathrm{~d},{ }^{3} \mathrm{~J}=4.9 \mathrm{~Hz}, 1 \mathrm{H}\right) .{ }^{13} \mathrm{C} \mathrm{NMR}\left(75 \mathrm{MHz}, \mathrm{CDCl}_{3}, 300 \mathrm{~K}\right): \delta$ $(\mathrm{ppm})=12.0 ; 18.9 ; 19.4 ; 21.2 ; 22.7 ; 22.9 ; 23.0 ; 24.4 ; 26.5 ; 27.7$; $28.2 ; 28.4 ; 32.0 ; 32.1 ; 36.0 ; 36.3 ; 36.7 ; 37.0 ; 37.9 ; 39.7 ; 39.9$; $42.5 ; 50.2 ; 56.3 ; 56.8 ; 76.3 ; 123.2 ; 139.3 ; 166.8$. MS MALDITOF: $\mathrm{m} / \mathrm{z}=506.71[\mathrm{M}+\mathrm{H}]^{+}$(calcd for $\mathrm{C}_{29} \mathrm{H}_{48} \mathrm{BrO}_{2}{ }^{+}: 507,28$ ), $530.27[\mathrm{M}+\mathrm{Na}]^{+}$(calcd for $\mathrm{C}_{29} \mathrm{H}_{47} \mathrm{BrNaO}_{2}{ }^{+}: 529,27$ ).

Cholesteryl (prop-2-ynyl-N,N-dimethylammonium bromide) acetate (11). Cholesteryl bromoacetate $9(250 \mathrm{mg}, 0.493$ $\mathrm{mmol}$ ) and dimethylpropargylamine $(57 \mu \mathrm{L}, 0.542 \mathrm{mmol})$ in 10 $\mathrm{mL}$ of acetone were stirred under reflux for three hours. The white precipitate observed was filtered off, wased one time with acetone, and dried under reduced pressure to afford the ammonium derivative 11 (227 mg, $78 \%$ ). ${ }^{1} \mathrm{H}$ NMR (300 MHz, $\left.\mathrm{CDCl}_{3}, 300 \mathrm{~K}\right): \delta(\mathrm{ppm})=0.68(\mathrm{~s}, 3 \mathrm{H}) ; 0.86-1.70(\mathrm{~m}, 34 \mathrm{H}) ; 1.75-$ $2.07(\mathrm{~m}, 4 \mathrm{H}) ; 2.36(\mathrm{~m}, 2 \mathrm{H}) ; 2.87(\mathrm{t}, 4 \mathrm{~J}=2.5 \mathrm{~Hz}, 1 \mathrm{H}) ; 3.72(\mathrm{~s}, 6 \mathrm{H})$; $4.71(\mathrm{~m}, 1 \mathrm{H}) ; 4.98(\mathrm{~s}, 2 \mathrm{H}) ; 5.08(\mathrm{~s}, 2 \mathrm{H}) ; 5.40(\mathrm{~d}, 3 \mathrm{~J}=4.9 \mathrm{~Hz}, 1 \mathrm{H})$. MS ESI: $\mathrm{m} / \mathrm{z}=510.37\left[\mathrm{M}-\mathrm{Br}^{-}\right]^{+}\left(\right.$calcd for $\left.\mathrm{C}_{34} \mathrm{H}_{56} \mathrm{NO}_{2}{ }^{+}: 510,43\right)$.

Cholesteryl (2-azidoethyl-N, $\mathrm{N}$-dimethylammonium bromide) acetate (12). Cholesteryl bromoacetate 9 (173 $\mathrm{mg}, 0.34 \mathrm{mmol})$ and 2-azido-N,N-dimethylethanamine 10 (74 mg, $0.65 \mathrm{mmol})$ were dissolved in $10 \mathrm{~mL}$ of acetone. The mixture was stirred under reflux for three hours. The white precipitate formed was filtered off, washed with acetone $(20 \mathrm{~mL})$, and dried under reduced pressure to afford the ammonium derivative 12 (64.3 $\mathrm{mg}, 78 \%) .{ }^{1} \mathrm{H}$ NMR (300 MHz, MeOD, $\left.300 \mathrm{~K}\right): \delta(\mathrm{ppm})=0.61(\mathrm{~s}$, $3 \mathrm{H}) ; 0.87-2.11(\mathrm{~m}, 40 \mathrm{H}) ; 2.41(\mathrm{~m}, 2 \mathrm{H}) ; 3.35(\mathrm{~s}, 6 \mathrm{H}) ; 3.83(\mathrm{~m}$, $2 \mathrm{H}) ; 3.97(\mathrm{~m}, 2 \mathrm{H}) ; 4.73(\mathrm{~m}, 1 \mathrm{H}) ; 5.40(\mathrm{~d}, 3 \mathrm{~J}=4.9 \mathrm{~Hz}, 1 \mathrm{H})$. MS MALDI-TOF: $\mathrm{m} / \mathrm{z}=540.56[\mathrm{M}-\mathrm{Br}]^{+}$(calcd for $\mathrm{C}_{33} \mathrm{H}_{57} \mathrm{~N}_{4} \mathrm{O}_{2}{ }^{+}$: 541,45).

2-chloro-N,N-dimethylethanamine hydrochloryde (13. $\mathrm{HCl})$. In a round bottom flask was introduced dimethylaminoethanol $(20 \mathrm{~mL}, 199 \mathrm{mmol})$, then thionyl chloride $(14.5 \mathrm{~mL}, 200 \mathrm{mmol}$ ) was slowly added under stirring and at low temperature (ice bath). After completion of the addition, the visquous reaction mixture was left at room temperature for $3 \mathrm{~h}$, then $100 \mathrm{~mL}$ of ethanol were added. The precipitate formed was filtered off, and the filtrate was put in an ice bath for $1 \mathrm{~h}$. The crystals of chlorhydrate 13 formed were filtered off and dried under reduced pressure. The filtrate was concentrated under 
vacuum, and cooled in an ice bath to afford more product $(9.3$ g, $32 \%)$.

2-chloro-N,N-dimethylethanamine (13). To a solution of sodium carbonate $(3 \mathrm{~g}, 28.3 \mathrm{mmol})$ in water $(10 \mathrm{~mL})$ was added 2-chloro-N,N-dimethylethanamine hydrochloride (2 g, 13.9), and the mixture was stirred for $10 \mathrm{~min}$. The product was extracted three times with diethyl ether $(3 \times 10 \mathrm{~mL})$ and the organic layer was dried with magnesium sulfate. After evaporation, the product was obtained as a colorless oil. ${ }^{1} \mathrm{H}$ $\operatorname{NMR}\left(300 \mathrm{MHz}, \mathrm{CDCl}_{3}, 300 \mathrm{~K}\right): \delta(\mathrm{ppm})=2.33(\mathrm{~s}, 6 \mathrm{H}) ; 2.69(\mathrm{t}$, $3 \mathrm{~J}=6.7 \mathrm{~Hz}, 2 \mathrm{H}) ; 3.57(\mathrm{t}, 3 \mathrm{~J}=6.7 \mathrm{~Hz}, 2 \mathrm{H})$.

2-azido-N, $\mathrm{N}$-dimethylethanamine (10). A solution of 2-chloro$\mathrm{N}, \mathrm{N}$-dimethylethanamine $13(500 \mathrm{mg}, 4.65 \mathrm{mmol})$ and sodium azide $(670 \mathrm{mg}, 10.31 \mathrm{mmol})$ in water $(12.5 \mathrm{~mL})$ was stirred at $60^{\circ} \mathrm{C}$ for $40 \mathrm{~h}$. After cooling the reaction mixture to room temperature, $0.5 \mathrm{~g}$ of potassium hydroxyde were added (ice bath), and the product was extracted with diethyl ether $(2 \times 25$ $\mathrm{mL})$. The combined organic layers were dried over magnesium sulfate and concentrated under vacuum. The residue was dried under reduced pressure to afford a colorless oil $(317 \mathrm{mg}, 60$ \%). ${ }^{1} \mathrm{H}$ NMR $\left(300 \mathrm{MHz}, \mathrm{CDCl}_{3}, 300 \mathrm{~K}\right): \delta(\mathrm{ppm})=2.28(\mathrm{~s}, 6 \mathrm{H})$; $2.51\left(\mathrm{t},{ }^{3} \mathrm{~J}=6.2 \mathrm{~Hz}, 2 \mathrm{H}\right) ; 3.35\left(\mathrm{t},{ }^{3} \mathrm{~J}=6.2 \mathrm{~Hz}, 2 \mathrm{H}\right) .{ }^{13} \mathrm{C}$ NMR $(75$ $\left.\mathrm{MHz}, \mathrm{CDCl}_{3}, 300 \mathrm{~K}\right): \delta(\mathrm{ppm})=45.6,49.2,58.2$.

$\begin{array}{ll}\text { Acronyms } & \\ \text { BBN } & \text { Bombesin } \\ \text { BBN-Chol } & \text { Bombesin-cholesterol derivative } \\ \text { BCN } & \text { Bicyclononyne } \\ \text { FPLC } & \text { Fast protein liquid chromatography } \\ \text { HPLC } & \text { High performance liquid chromatography } \\ \text { SubPc } & \text { Subphthalocyanine } \\ \text { DPPC } & \text { 1,2-dipalmitoyl-sn-glycero-3-phosphocholine? } \\ \text { Trt } & \text { Trityl } \\ \text { Boc } & \text { tert-Butoxycarbonyl } \\ \text { Mmt } & \text { 4,4'-Dimethoxytrityl }\end{array}$

\section{Acknowledgements}

RAD, YB thank the Burgundy Regional Council, CRB (FABER Program), RAD thanks CNRS for Chaire d'Excellence. This work was supported by the $3 M I M$ agreement (CNRS, uB and CRB). MM thanks ANR (Equipex IMAPPI). We also thank France Life Imaging (FLI).

1 E.M.C. Hillman, C. B. Amoozegar, T. Wang, A. F. H. McCaslin, M. B. Bouchard, J. Mansfield, R. M. Levenson, Philosophical Trans. Royal Soc. A-Mathematical Physical and Engineering Sciences, 2011, 369, 4620.

2 E. Heyer, P. Lory, J. Leprince, M. Moreau, A. Romieu, M. Guardigli, A. Roda, R. Ziessel, Angew. Chem. Int. Ed. 2015, 54, 2995.

3 a) Y. Bernhard, P. Winckler, R. Chassagnon, P. Richard, E. Gigot, J.-M. Perrier-Cornet, R. A. Decreau, R. A. Chem. Commun. 2014, 50, 13975; b) Y Bernhard, P Winckler, J.-M Perrier-Cornet, R. A. Decréau, Dalton Transactions 2015, 44, 3200.

4 a) R. Decreau, M. Julliard, M. Chanon, M. Synlett, 1998, 4, 375; b) Y. Ooyama, S. Yoshikawa, S. Watanabe, K. Yoshida
Org. Biomol. CheM. 2007, 5, 1260; c) P.-E. Doulain, C. Goze, E. Bodio, P. Richard, R. A. Decreau, Chem. Commun. 2016, 52, 4474.

5 L. D. Lavis and R. T. Raines, ACS Chem. Biol. 2008, 3, 142.

6 K. Adachi and H. Watarai, Anal. Chem. 2006, 78, 6840.

7 a) L. Ma, P. Yu, B. Veerendra, T. L. Rold, L. Retzloff, A. Prasanphanich, G. Sieckman, T. J. Hoffman, W. A. Volkert, C. J. Smith, Molecular Imaging, 2007, 6, 171; b) P.-E. Doulain, R. A. Decreau, C. Racoeur, V. Goncalves, L. Dubrez, A. Bettaeib, P. Le Gendre, F. Denat, C. Paul, C. Goze, E. Bodio, Dalton Trans. 2015, 4874; c) B. Brizet, V. Goncalves, C. Bernhard, P. D. Harvey, F. Denat, C. Goze, Chem. Eur. J. 2014, 20, 12933.

8 C. G. Claessens D. Gonzalez-Rodriguez, B. del Rey, T. Torres, G. Mark, H. P. Schuchmann C. von Sonntag, J. G. MacDonald, R. S. Nohr, Eur. J. Org. Chem. 2003, 2547.

9 Liposomes, a practical Approach. R R C New Editions. IRL Press, 1989; b) S. Batzri, E. D. Korn, Biochim. Biophys. Acta 1980, 594, 53; c) R. Decréau, M.-J. Richard, P. Verrando, M. Chanon, M. Julliard, J. Photochem. Photobiol. B: Biol, 1999, 48, 48; d)J. Barge, R. Decreau, M. Julliard, J. C. Hubaud, A. S. Sabatier, J. J. Grobb, P. Verrando, Exp. Dermatol. 2004, 13, 33; e) R. Decreau, A. Viola, M. J. Richard, A. Jeunet, M. Julliard, J. Porph Phthalocyanines, 1998, 2, 405.

10 a) P. Vabbilisetty, X.-L. Sun, Org. Biomol Chem. 2014, 12, 1237; b) A. S. Gupta, H. A. von Recum, (2014) Bioconjugation Strategies: Lipids, Liposomes, Polymersomes, and Microbubbles, in Chemistry of Bioconjugates: Synthesis, Characterization, and Biomedical Applications (ed R. Narain), John Wiley \& Sons, Inc., Hoboken, NJ, USA; pp 185.

11 S. Guard, K. J. Watling, W. Howson, Eur. J. Pharmacol. 1993, 240, 177.

12 V. Sancho Bornez, A. Di Florio, T. W. Moody, R. T. Jensen, Curr. Drug Delivery, 2011, 8, 79. 